\title{
Conservation implications of the genetic diversity of Gymnospermium microrrhynchum in Korea
}

\author{
S.H. Lee, M.H. Yeon and J.K. Shim \\ Laboratory of Ecology, Department of Life Science, Chung Ang University, \\ Seoul, South Korea \\ Corresponding author: J.K. Shim \\ E-mail:shimjk@cau.ac.kr
}

Genet. Mol. Res. 15 (4): gmr15048843

Received June 2, 2016

Accepted July 20, 2016

Published October 24, 2016

DOI http://dx.doi.org/10.4238/gmr15048843

Copyright $(2016$ The Authors. This is an open-access article distributed under the terms of the Creative Commons Attribution ShareAlike (CC BY-SA) 4.0 License.

\begin{abstract}
Gymnospermium microrrhynchum (Berberidaceae) is an ephemeral perennial herb with a limited distributional range in the Baekdudaegan mountain areas of the Korean Peninsula, and is designated a rare plant by the Korean Forest Service. Information about its genetic variation and structure is important for developing successful conservation strategies. To investigate the genetic variation within and among seven G. microrrhynchum populations, random amplified polymorphic DNA data were obtained for 207 individuals. The populations exhibited relatively low genetic diversity: the percentage of polymorphic bands (PPB) ranged from 32.1 to $66.7 \%$ (mean $=51.4 \%)$ and Nei's gene diversity $\left(H_{\mathrm{E}}\right)$ ranged from 0.116 to 0.248 (mean = 0.188 ). However, genetic diversity at the species level was relatively high ( $\left.\mathrm{PPB}=98.7 \%, H_{\mathrm{E}}=0.349\right)$. An analysis of molecular variance revealed high differentiation among populations $\left(F_{\mathrm{ST}}=0.6818\right)$, but the low gene flow value $\left(N_{\mathrm{m}}=0.117\right)$ suggests a low level of gene
\end{abstract}


exchange occurs among populations. Principal coordinates analysis revealed that individuals were separated according to population. The high level of genetic differentiation and restricted gene flow among $G$. microrrhynchum populations, which resulted from their isolation in alpine areas after the Ice Age, indicates that it is essential to protect and manage all populations, rather than focus on specific populations, in order to maintain the genetic diversity of this species.

Key words: Genetic diversity; Gymnospermium microrrhynchum; Plant conservation; RAPD

\section{INTRODUCTION}

Genetic variation provides the resources on which populations rely to survive against drastic environmental changes and evolutionary adaptations (Liu et al., 2016a). Species adapted to local environments, or isolated for long periods, have low levels of genetic variation and are easily affected by small environmental changes (Hamrick et al., 1992). Therefore, the level of genetic variation is usually a good indicator of the geographical history of the taxon and the set of events it has been exposed to, and it provides basic information to maintain genetic variation (Frankham et al., 2002) or establish effective conservation strategies for target species (Yu et al., 2011).

Gymnospermium microrrhynchum (S. Moore) Takht. (Berberidaceae) is a perennial herb that is distributed throughout Manchuria, Northeast China, and the Korean Peninsula, where it is restricted to the high-altitude Baekdudaegan [about $1000 \mathrm{~m}$ above mean sea level (AMSL)] mountain range, which constitutes the species' southern limit (Lee et al., 2011). G. microrrhynchum is facing a high risk of extinction because of its small number of regional groups and habitat destruction and fragmentation (Chang et al., 2005). It is designated a rare plant by the Korean Forest Service and rated as vulnerable in the Rare Plants in Korea Data Book because of concerns about habitat destruction caused by climate change (Chang et al., 2005; Korean National Arboretum, 2012).

The genetic variability and partitioning of a plant species reflects the life history traits that are crucial for its adaptation, such as breeding system, seed dispersal mechanism, geographical range, and genetic diversity (Nybom and Bartish, 2000; Nybom, 2004). Quaternary climate change probably played a major role in determining the current distributions and genetic variation of plant species (Hewitt, 2004; Chung et al., 2013). G. microrrhynchum prefers cool climates, and might have had a wider distribution during the Ice Age than it currently does (Kong, 2002). However, after the Holocene, its center of distribution probably moved north as the climate became warmer, or the species might have been isolated in alpine regions where temperatures were low. During the Late Pleistocene, the Baekdudaegan mountain range might have provided refugia for species adapted to low temperatures on the Korean Peninsula (Kong and Lim, 2008). Climate change due to global warming may result in warmer habitats, which are unfavorable for boreal plant species such as G. microrrhynchum, particularly in high-altitude regions. Therefore, monitoring these populations is invaluable in evaluating their responses to climate change, and for estimating their future status.

Molecular markers have been widely used to characterize the population genetic

Genetics and Molecular Research 15 (4): gmr15048843 
structures of plant species (Liu et al., 2012), and DNA-based markers have been particularly informative because, unlike morphological and biochemical markers, they are not prone to environmental influence. Random amplified polymorphic DNA (RAPD) is a useful method to determine several genetic parameters of rare and endangered plants, as it requires low amounts of plant tissue (Trindade et al., 2012) and obtains DNA fingerprints without accessing genome sequence information (Liu et al., 2012; Rodrigues et al., 2013).

Despite its vulnerable status and scattered distribution, no investigation has been undertaken on G. microrrhynchum using molecular markers, except for the study by Chang et al. (2005) using allozymes. In the present study, we used RAPD to evaluate the genetic variation within and among populations of G. microrrhynchum. The main objectives of this study were to 1) assess the levels of genetic diversity of natural populations, 2) ascertain the partitioning of genetic variation within and among populations, 3) investigate the natural history of the species, and 4) provide basic information for G. microrrhynchum conservation.

\section{MATERIAL AND METHODS}

\section{Study plant and its distributional characteristics}

G. microrrhynchum is a polycarpic perennial and early spring ephemeral herb (Lee, 2003), which is rooted at 20-30 cm depth. It blooms in April, and the racemes bear approximately 10-20 bright yellow flowers at the end of the stem; the flowers have six petals and the stipule is a phyllode. The pedicle becomes increasingly short, to around $3 \mathrm{~cm}$ long (Lee, 1997, 2003). The stem grows to about $30-40 \mathrm{~cm}$ aboveground, and has biternate leaves surrounded by complete stipules. The fruit is a round capsule and ripens in May. Due to its rarity, the Korean Ministry of the Environment listed G. microrrhynchum as an endangered species, but it was removed from this list in 2012 following the discovery of new habitats (Ministry of Environment, 2012). Nevertheless, this species is still listed as rare by the Korean Forest Service (Korean National Arboretum, 2012).

G. microrrhynchum has a limited distributional range in the Taebaek Mountains (Baekdudaegan, Korean Peninsula). Mt. Taebaek (3706'31"N, 128 54'30"E; around $1163 \mathrm{~m}$ AMSL) is its southern limit; its lower altitude limit (684 m AMSL) is in Baekbong-ryung $\left(37^{\circ} 32^{\prime} 08^{\prime \prime} \mathrm{N}, 128^{\circ} 56^{\prime} 45^{\prime \prime} \mathrm{E}\right)$. The seven populations of G. microrrhynchum considered in this study (Figure 1) were sampled from gentle slopes or ridges (Table 1), in a narrow thermal climatic area characterized by a Warmth Index (WI) of between $50^{\circ}-75^{\circ} \mathrm{C} \cdot$ month, with an average of $59.7^{\circ} \pm 6.3^{\circ} \mathrm{C} \cdot$ month (Figure 2). The WI is calculated by summing all of the monthly mean temperatures above $5^{\circ} \mathrm{C}$ (Yim and Kira, 1975). Therefore, all of the G. microrrhynchum populations studied were in a cool temperate forest zone (Yim, 1977).

\section{Sampling}

Two or three young and intact leaflets were randomly collected from 207 individuals belonging to the seven populations of G. microrrhynchum (approximately 30 individuals per population, Table 1) that were approximately $10 \mathrm{~m}$ apart from each other during the early growing season (April to May 2010). Immediately after collection, the leaf samples were placed inside a vinyl bag containing a solid moisture absorbent. The leaf samples were preserved at $-20^{\circ} \mathrm{C}$ in the laboratory until DNA extraction.

Genetics and Molecular Research 15 (4): gmr15048843 


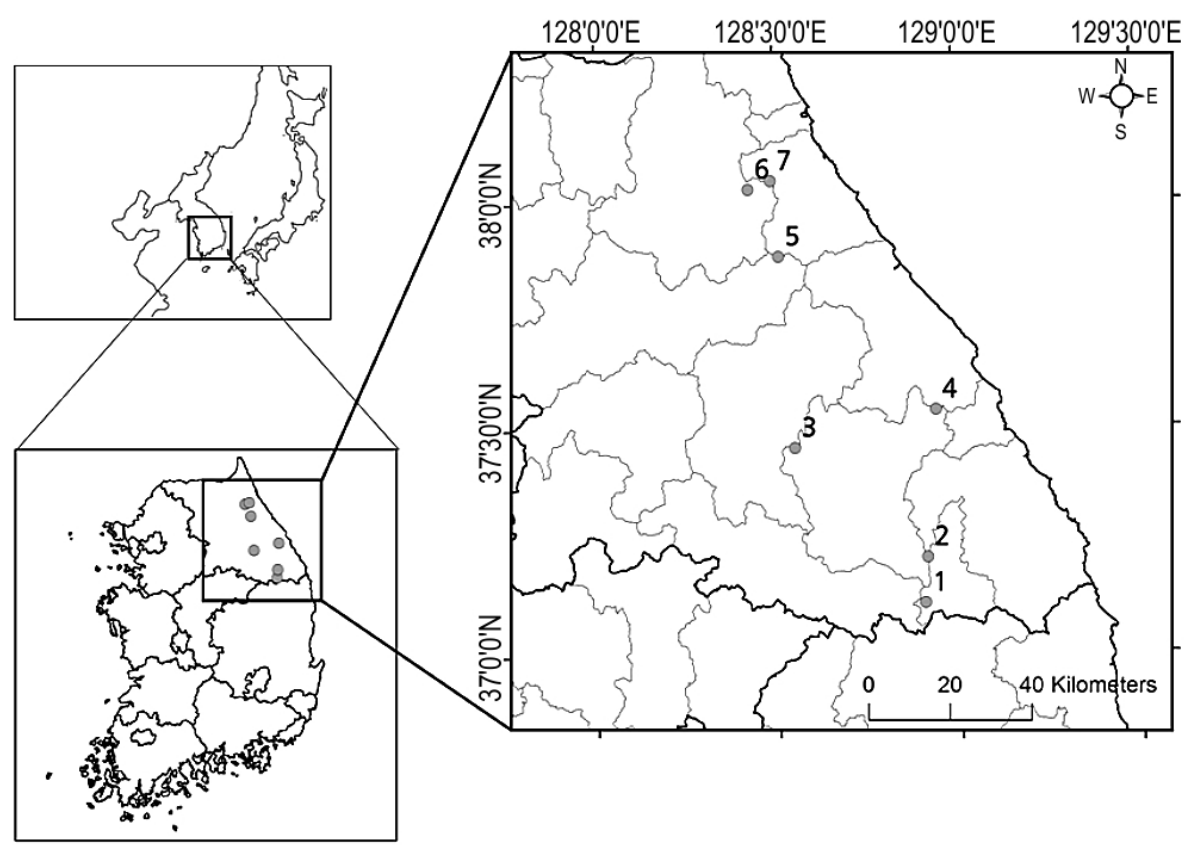

Figure 1. Distribution of the Gymnospermium microrrhynchum populations considered in this study. $1=\mathrm{TB}$, Mt. Taebaek. 2 = GD, Geumdae-bong. 3 = GR, Mt. Gariwang. 4 = BB, Baekbong-ryung. 5 = GuR, Guryong-ryung. 6 $=\mathrm{GB}$, Gombae-ryung. $7=$ BA, Bukam-ryung.

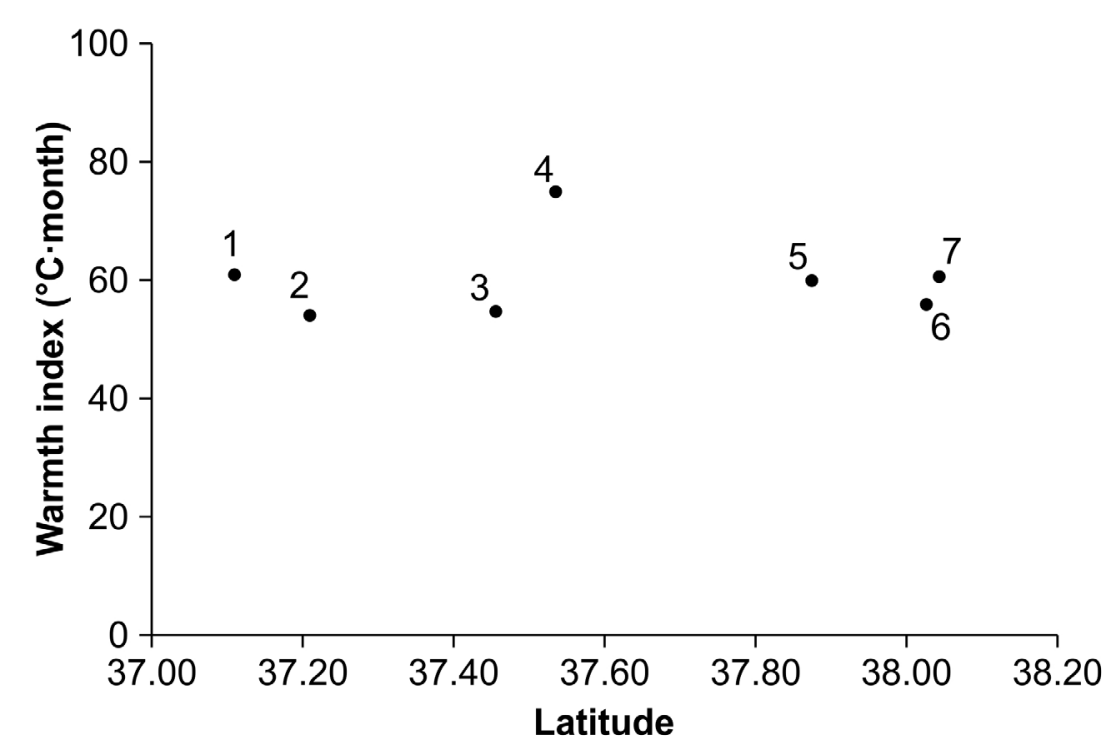

Figure 2. Geographical and thermal climatological distribution of Gymnospermium microrrhynchum populations on the Korean Peninsula. $1=$ Mt. Taebaek. $2=$ Geumdae-bong. $3=$ Mt. Gariwang. $4=$ Baekbong-ryung. $5=$ Guryong-ryung. 6 = Gombae-ryung. 7 = Bukam-ryung.

Genetics and Molecular Research 15 (4): gmr15048843 
Table 1. Characteristics of the sampling locations and sample sizes of each Gymnospermium microrrhynchum population studied.

\begin{tabular}{l|l|c|c|c|c|c|c}
\hline No. & Population* & Latitude & Longitude & Altitude $(\mathrm{m})$ & Slope $\left(^{\circ}\right)$ & Slope orientation & Sample size (N) \\
\hline 1 & Mt. Taebaek (TB) & $37^{\circ} \mathrm{N} 06^{\prime} 31^{\prime \prime}$ & $128^{\circ} \mathrm{E} 54^{\prime} 30^{\prime \prime}$ & 1163 & 10 & $\mathrm{NE}$ & 30 \\
\hline 2 & Mt. Geumdae (GD) & $37^{\circ} \mathrm{N} 12^{\prime} 34^{\prime \prime}$ & $128^{\circ} \mathrm{E} 54^{\prime} 59^{\prime \prime}$ & 1353 & 17 & $\mathrm{NW}$ & \\
\hline 3 & Mt. Gariwang (GR) & $37^{\circ} \mathrm{N} 27^{\prime} 17^{\prime \prime}$ & $128^{\circ} \mathrm{E} 33^{\prime} 12^{\prime \prime}$ & 1294 & 10 & $\mathrm{NW}$ & 30 \\
\hline 4 & Baekbong-ryung (BB) & $37^{\circ} \mathrm{N} 32^{\prime} 08^{\prime \prime}$ & $128^{\circ} \mathrm{E} 56^{\prime} 45^{\prime \prime}$ & 684 & 25 & $\mathrm{SW}$ & 30 \\
\hline 5 & Guryong-ryung (GuR) & $37^{\circ} \mathrm{N} 52^{\prime} 37^{\prime \prime}$ & $128^{\circ} \mathrm{E} 30^{\prime} 54^{\prime \prime}$ & 1077 & 23 & $\mathrm{E}$ & 29 \\
\hline 6 & Gombae-ryung (GB) & $38^{\circ} \mathrm{N} 01^{\prime} 34^{\prime \prime}$ & $128^{\circ} \mathrm{E} 25^{\prime} 57^{\prime \prime}$ & 1163 & 12 & $\mathrm{SE}$ & 30 \\
\hline 7 & Bukam-ryung (BA) & $38^{\circ} \mathrm{N} 02^{\prime} 42^{\prime \prime}$ & $128^{\circ} \mathrm{E} 29^{\prime} 42^{\prime \prime}$ & 1030 & 8 & $\mathrm{~N}$ & 28 \\
\hline
\end{tabular}

*The acronym used for each population is indicated in parentheses.

\section{DNA extraction and RAPD}

Frozen leaf samples were placed in liquid nitrogen and ground using a mortar and pestle. DNA was extracted from the powdered leaf samples using a DNeasy ${ }^{\mathbb{B}}$ Plant Mini Kit (Qiagen, Almeda, CA, USA), and its quantity and quality were verified using a NanoDrop ${ }^{\circledR}$ ND-1000 Spectrophotometer (NanoDrop Technologies, DE, USA). Each DNA sample was diluted to $25 \mathrm{ng} / \mu \mathrm{L}$ with $0.5 \mathrm{X}$ TE buffer before conducting a RAPD-polymerase chain reaction (PCR). Of the 100 RAPD primers (Operon RAPD ${ }^{\circledR} 10$-mer kit, Qiagen) from the A, C, D, E, F, P, O, N, W, and AF series screened, eight were selected for this study based on their reproducible and distinct banding patterns (Table 1). PCRs were performed in a total volume of $20 \mu \mathrm{L}$ that contained $25 \mathrm{ng}$ genomic DNA, $1 \mathrm{U}$ Taq DNA polymerase (TaKaRa Bio Inc., Otsu, Japan), $2.0 \mu \mathrm{L}$ 10X PCR buffer, $1.0 \mu \mathrm{L}$ dNTP mixture (2.5 mM each), $2.0 \mu \mathrm{L}$ primer (20 pmol), and double-distilled water. PCR amplifications were conducted in a TProfessional Basic Thermocycler (Biometra, Goettingen, Germany) under the following conditions: initial denaturation at $94^{\circ} \mathrm{C}$ for $2 \mathrm{~min} ; 39$ cycles at $94^{\circ} \mathrm{C}$ for $30 \mathrm{~s}$ (denaturation), $36^{\circ} \mathrm{C}$ for $30 \mathrm{~s}$ (annealing), and $72^{\circ} \mathrm{C}$ for $1 \mathrm{~min}$ (extension); with a final extension at $72^{\circ} \mathrm{C}$ for $10 \mathrm{~min}$. The PCR products were subjected to electrophoresis on 1.4\% agarose gels in $0.5 \mathrm{X}$ TAE buffer, and visualized under ultraviolet light using ethidium bromide. Band patterns were photographed using a Gel Doc ${ }^{\mathrm{TM}} 2000$ gel Imaging System (Bio-Rad Laboratory Inc., Hercules, CA, USA).

\section{Data analysis}

Each RAPD fragment was scored as either present (1) or absent (0) and a binary data matrix was obtained. Genetic variation was then determined based on the percentage of polymorphic bands (PPB) in relation to total bands, Nei's (1978) gene diversity $\left(H_{\mathrm{E}}\right)$, the observed number of alleles per locus $\left(A_{\mathrm{O}}\right)$, the effective number of alleles per locus $\left(A_{\mathrm{E}}\right)$, and Shannon's information index $(I)$ using POPGENE v. 1.32 (Yeh and Boyle, 1997).

To estimate the genetic differentiation within and among G. microrrhynchum populations, an analysis of molecular variance (AMOVA) was performed in ARLEQUIN ver. 3.1 (Excoffier et al., 2007) and the genetic differentiation coefficient $F_{\text {ST }}$ was calculated. Gene flow, i.e., the proportion of new immigrant genes moving into the population, was determined using the formula $N_{\mathrm{m}}=1 / 4\left(1-F_{\mathrm{ST}}\right) / F_{\mathrm{ST}}$ (Slatkin and Barton, 1989), where $N$ is the effective population size and $m$ is the migration rate.

To investigate the relationships between individuals within a single population and among populations, an unweighted pair-group method with arithmetic average (UPGMA) cluster analysis was performed based on the RAPD binary matrix using POPGENE v. 1.32.

Genetics and Molecular Research 15 (4): gmr15048843 
Genetic distance (Nei, 1978) was calculated using POPGENE v. 1.32, and geographical distances were calculated using Google Earth (www.google.com/earth). A Mantel test (Mantel, 1967) was performed to investigate correlations between the G. microrrhynchum populations' genetic and geographical distances using GenAIEx v. 6.5 (Peakall and Smouse, 2006). A principal coordinates analysis (PCoA) was performed in GenAIEx v. 6.5 based on the binary RAPD matrix, and three-dimensional Euclidian distances were calculated for all pairwise comparisons of the G. microrrhynchum individuals. The PCoA results were plotted in the space defined by the first and second PCoA axes in GenAIEx v. 6.5. All of the statistical analyses considered $\mathrm{P}<0.05$ as significant.

\section{RESULTS}

\section{G. microrrhynchum genetic diversity}

The average number of bands per primer was 9.75 (Table 2). At the species level, 77 of 78 RAPD-PCR bands had polymorphic loci (98.7\% polymorphism) (Table 3). However, the PPB within each population ranged from 32.1 to $66.7 \%$, and the mean PPB for the seven populations was $51.4 \%$ (Table 3 ).

Table 2. Primers used in the random amplified polymorphic DNA-polymerase chain reaction and their sequences, and the number of loci and polymorphic loci obtained in this analysis.

\begin{tabular}{l|l|c|c}
\hline Primer & Sequence (3'-5') & Number of loci & Number of polymorphic loci \\
\hline OPA-08 & GTGACGTAGG & 10 & 10 \\
\hline OPA-10 & GTGATCGCAG & 9 & 9 \\
\hline OPAF-07 & GGAAAGCGTC & 10 & 10 \\
\hline OPAF-20 & CTCCGCACAG & 10 & 10 \\
\hline OPN-03 & GGTACTCCCC & 10 & 13 \\
\hline OPN-13 & AGCGTCACTC & 13 & 11 \\
\hline OPO-06 & CCACGGGAAG & 4 & 4 \\
\hline OPP-05 & CCCCGGTAAC & 9.75 & 9.63 \\
\hline Mean & & & \\
\hline
\end{tabular}

Table 3. Genetic diversity of the seven Gymnospermium microrrhynchum populations according to different indices.

\begin{tabular}{l|c|c|c|c|c}
\hline Population & PPB & $A_{O}$ & $A_{E}$ & $H_{E}$ & $I$ \\
\hline BA & 66.7 & 1.667 & 1.426 & 0.245 & 0.362 \\
\hline GB & 65.4 & 1.654 & 1.433 & 0.248 & 0.364 \\
\hline BB & 58.7 & 1.590 & 1.354 & 0.216 & 0.324 \\
\hline GD & 55.1 & 1.551 & 1.275 & 0.176 & 0.272 \\
\hline GuR & 48.7 & 1.487 & 1.312 & 0.182 & 0.269 \\
\hline GR & 33.3 & 1.333 & 1.185 & 0.116 & 0.176 \\
\hline TB & 32.1 & 1.321 & 1.247 & 0.136 & 0.196 \\
\hline Mean & 51.4 & 1.515 & 1.319 & 0.188 & 0.280 \\
\hline Total & 98.7 & 1.987 & 1.613 & 0.349 & 0.517 \\
\hline
\end{tabular}

$\mathrm{PPB}$, percentage of polymorphic bands; $A_{\mathrm{O}}$, observed number of alleles per locus; $A_{\mathrm{E}}$, effective number of alleles per locus; $H_{\mathrm{E}}$, Nei's gene diversity; $I$, Shannon's information index. BA, Bukam-ryung; GB, Gombae-ryung; BB, Baekbong-ryung; GD, Geumdae-bong; GuR, Guryong-ryung; GR, Mt. Gariwang; TB, Mt. Taebaek. 
The G. microrrhynchum populations exhibited different degrees of genetic diversity (Table 3); however, all of the genetic diversity indices revealed a significant close relationship $\left(R^{2}=0.837-0.999, \mathrm{P}<0.05\right)$. The genetic diversity of each population reflected its latitudinal position: the two most northern populations, Bukam-ryung (BA) and Gombae-ryung (GB), had the highest genetic diversity, whereas the southernmost population, Mt. Taebaek (TB), had the lowest. PPB, $H_{\mathrm{E}}$, and $I$ in the BA and GB populations were 66.7 and 65.4, 0.245 and 0.248 , and 0.362 and 0.364 , respectively. In contrast, TB had $32.1 \mathrm{PPB}, 0.136 H_{\mathrm{E}}$, and 0.196 $I$, which were about half the values found in BA and GB (Table 3). These results suggest that the G. microrrhynchum populations originated in the north (Kong, 2002), and that the Korean Peninsula is their southern distributional limit (Figure 3).

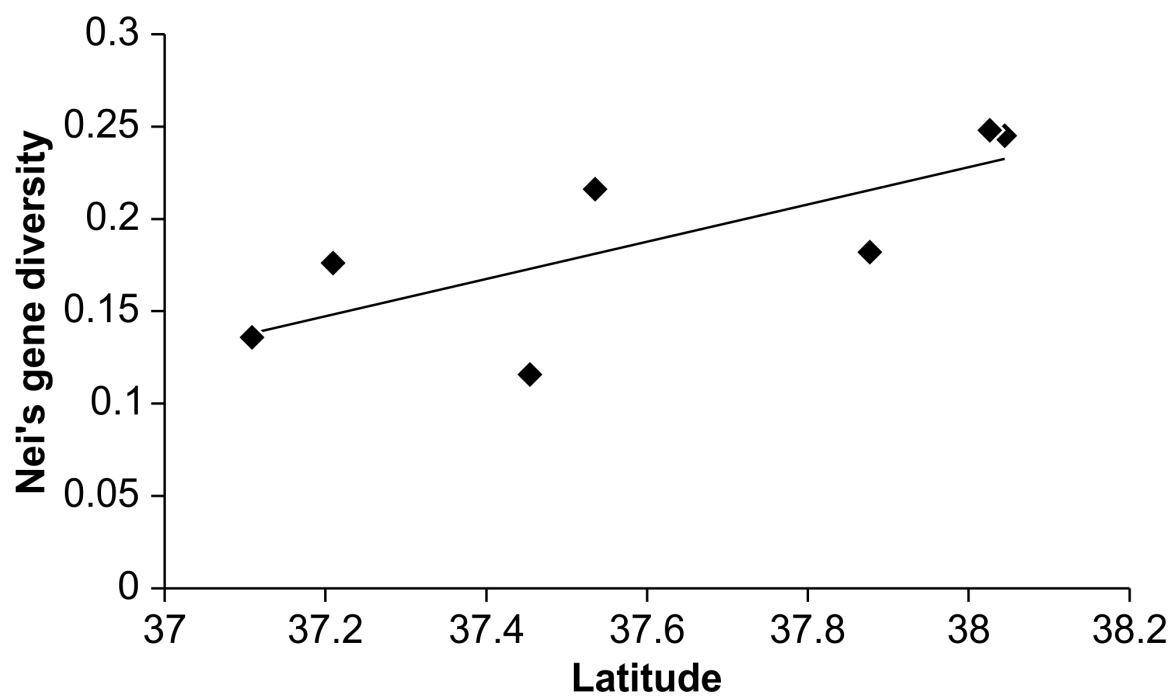

Figure 3. Relationship between latitude and Nei's genetic diversity in the Gymnospermium microrrhynchum populations analyzed. The regression is $y=0.1007 x-3.5995(R=0.566, \mathrm{P}<0.05)$.

Geographically intermediate sites, such as Guryong-ryung (GuR), Mt. Gariwang (GR), Mt. Geumdae (GD), and Baekbong-ryung (BB), had intermediate genetic diversity values (Table 3). Although GR, GD, and BB had relatively high genetic diversity considering their latitude, GuR had relatively low genetic diversity relative to the latitudinal gradient.

The genetic diversity of G. microrrhynchum at the species level was higher than that at the population level (Table 3), with PPB reaching 98.7, $H_{E}$ being 0.349 , and $I$ attaining 0.517 . These values were not only higher than the mean genetic diversity values calculated for the seven populations studied, but also higher than the values obtained for BA and GB, which had the highest values amongst the studied populations.

\section{Genetic structure of G. microrrhynchum populations}

AMOVA was performed to examine the distribution of total genetic variation among and within populations. The results showed that $68.18 \%$ of the total genetic variation was due to differences among populations and $32.82 \%$ to differences among individuals within 
populations (Table 4). Both variance components were highly significant $(\mathrm{P}<0.001)$. The higher value of genetic differentiation among populations than within populations indicates that gene exchange among local G. microrrhynchum populations was low, which agrees with the low $N_{\mathrm{m}}$ value ( 0.117 individuals per generation) that was calculated based on $F_{\mathrm{ST}}$ values among populations.

Table 4. Analysis of molecular variance among the seven Gymnospermium microrrhynchum populations studied.

\begin{tabular}{l|c|c|c|c}
\hline Source of variance & d.f. & Variance component & Genetic variation (\%) & P value \\
\hline Among populations & 6 & 8.6859 & 68.18 & $<0.001$ \\
\hline Within populations & 200 & 4.5408 & 32.82 & $<0.001$ \\
\hline
\end{tabular}

d.f., degrees of freedom.

The geographical distances measured between the seven studied populations are shown in Table 5 (above the diagonal), together with Nei's genetic distance (below the diagonal).

Table 5. Geographical distances (above diagonal, $\mathrm{km}$ ) and Nei's genetic distance (below diagonal) between Gymnospermium microrrhynchum populations.

\begin{tabular}{l|c|c|c|c|c|c|c}
\hline & BA & GB & GuR & GR & BB & GD & TB \\
\hline BA & - & 5.3 & 17.9 & 64.7 & 69.6 & 99.8 & 109.8 \\
\hline GB & 0.1859 & - & 17.9 & 63.8 & 63.9 & 100.3 & 110.1 \\
\hline GuR & 0.3457 & 0.2172 & - & 46.7 & 46.9 & 82.6 & 92.3 \\
\hline GR & 0.3092 & 0.3073 & 0.2818 & - & 36.4 & 41.9 & 49.4 \\
\hline BB & 0.2483 & 0.2027 & 0.2328 & 0.1742 & - & 37 & 48.1 \\
\hline GD & 0.2383 & 0.2655 & 0.3100 & 0.2232 & 0.2241 & - & 11.3 \\
\hline TB & 0.2996 & 0.2937 & 0.3605 & 0.1789 & 0.2749 & 0.2898 & - \\
\hline
\end{tabular}

BA, Bukam-ryung; GB, Gombae-ryung; GuR, Guryong-ryung; GR, Mt. Gariwang; BB, Baekbong-ryung; GD, Geumdae-bong; TB, Mt. Taebaek.

According to the Mantel test, the geographical and genetic distances were not significantly correlated $\left(R^{2}=0.132, \mathrm{P}>0.06\right)$. Therefore, there was no clear geographical tendency that explained the distribution of genetic variability among the G. microrrhynchum populations, despite the significant latitudinal gradient found for their genetic diversity: northern populations had higher values of genetic diversity than southern populations.

The UPGMA dendrogram that was constructed based on Nei's genetic distance between all G. microrrhynchum population pairs (Figure 4) revealed a close genetic relationship between BA and GB, which reflected their close geographical distance. These populations formed a cluster that was differentiated from a cluster comprising GR, BB, GD, and TB that were grouped according to their latitudinal similarity: these four populations were located in the southern part of G. microrrhynchum's distribution along the Korean Peninsula. The northern GuR population, although geographically close to BA and GB, was the most distantly related to the six other populations. Population BB had relatively high genetic diversity among the southern populations and almost identical genetic distances to all of the populations, although it did inhabit the lowest altitude (684 m AMSL).

The PCoA results of all of the G. microrrhynchum individuals in the seven populations studied are presented in Figure 5. Cumulatively, the first three vectors accounted for $64.1 \%$ of the total variance detected, each comprising $25.1,21.3$, and $17.7 \%$ of the total variance,

Genetics and Molecular Research 15 (4): gmr15048843 
respectively. A simple plot of the first two vectors revealed that most individuals tended to be separated according to their population, with the exception of individuals from TB and GR, which were grouped along the first vector.

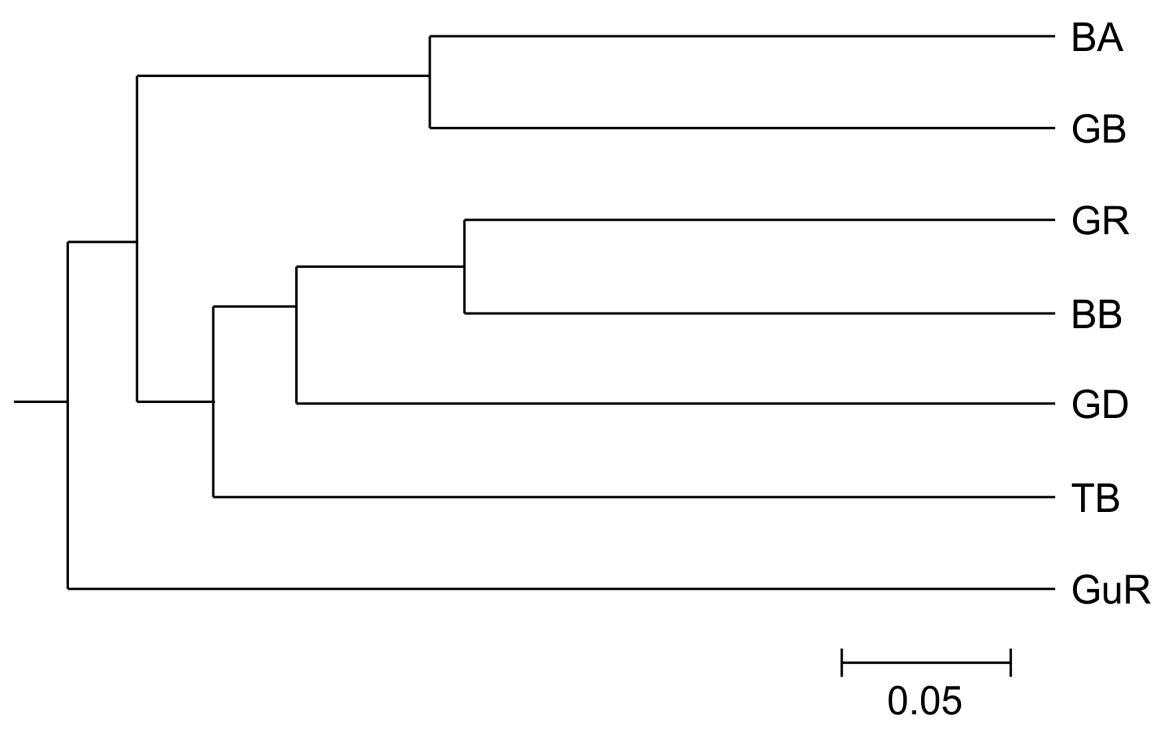

Figure 4. Unweighted pair-group method with arithmetic average dendrogram of Gymnospermium microrrhynchum populations. The scale bar represents Nei's genetic distance. TB, Mt. Taebaek; GD, Geumdae-bong; GR, Mt. Gariwang; BB, Baekbong-ryung; GuR, Guryong-ryung; GB, Gombae-ryung; BA, Bukam-ryung.

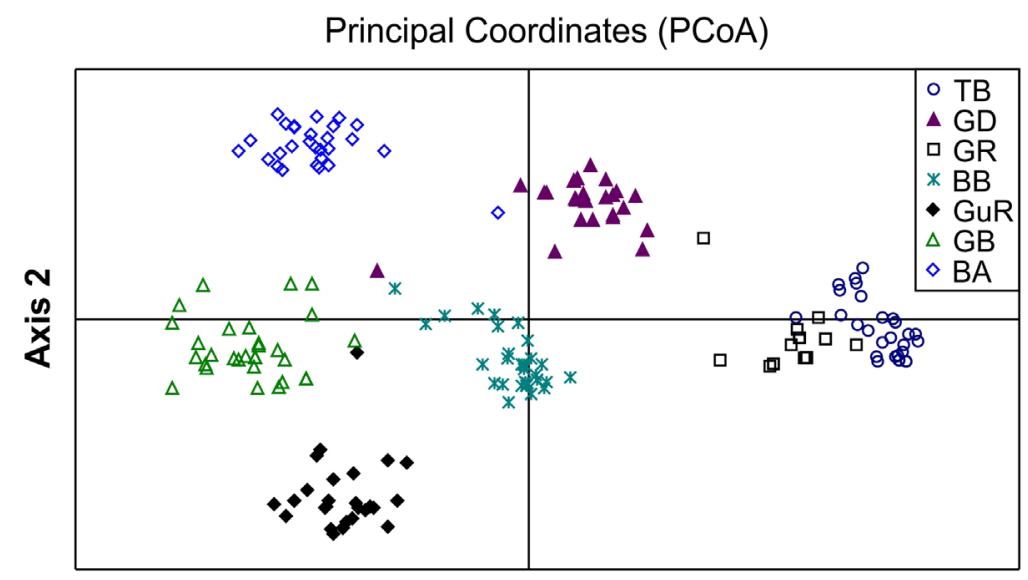

Axis 1

Figure 5. Principal coordinates analysis plot showing the random amplified polymorphic DNA banding pattern ordination of Gymnospermium microrrhynchum individuals in the space defined by the first two vectors (axes). TB, Mt. Taebaek; GD, Geumdae-bong; GR, Mt. Gariwang; BB, Baekbong-ryung; GuR, Guryong-ryung; GB, Gombaeryung; BA, Bukam-ryung.

Genetics and Molecular Research 15 (4): gmr15048843 


\section{DISCUSSION}

\section{Genetic diversity and structure of $G$. microrrhynchum populations}

The G. microrrhynchum populations studied here, which were distributed in the southern area of Baekdudaegan that is the backbone of the Korean Peninsula, exhibited higher genetic diversity at the species level than at the population level, as evidenced by the PPB, $H_{\mathrm{E}}$, and $I$ values. In addition, high genetic differentiation and low levels of gene flow were detected among the populations. At the species level, genetic diversity was relatively high ( $\mathrm{PPB}=98.7 \%$, $H_{\mathrm{E}}=0.3491$, and $\left.I=0.5171\right)$, whereas the average genetic diversity at the population level was relatively low $\left(\mathrm{PPB}=51.4 \%, H_{\mathrm{E}}=0.2084\right.$, and $\left.I=0.3101\right)$. Using RAPD or inter simple sequence repeat markers, similar results have been obtained for rare or endangered species such as Tuberaria major $\left(\mathrm{PPB}=97.66 \%, H_{\mathrm{E}}=0.197\right.$, and $I=0.324$ at the species level; $\mathrm{PPB}=$ $65.89 \%, H_{\mathrm{E}}=0.160$, and $I=0.259$ at the population level) (Trindade et al., 2012), Neopicrorhiza scrophulariflora $\left(\mathrm{PPB}=100.00 \%, H_{\mathrm{E}}=0.407\right.$, and $I=0.591$ at the species level; $\mathrm{PPB}=30.56 \%$, $H_{\mathrm{E}}=0.124$, and $I=0.179$ at the population level) (Liu et al., 2011), Dimorphandra mollis ( $\mathrm{PPB}=$ $40.00 \%, H_{\mathrm{E}}=0.124$, and $I=0.190$ at the species level; $\mathrm{PPB}=14.6 \%, H_{\mathrm{E}}=0.052$, and $I=0.078$ at the population level) (Viana e Souza and Lovato, 2010), and Mentha cervina $\left(\mathrm{PPB}=98.3 \%, H_{\mathrm{E}}\right.$ $=0.325$, and $I=0.23$ at the species level; $\mathrm{PPB}=44.4 \%, H_{\mathrm{E}}=0.151$, and $I=0.23$ at the population level) (Rodrigues et al., 2013). The most plausible explanation for the high genetic diversity found at the species level is a high level of genetic differentiation among populations (Rodrigues et al., 2013), which was supported by the AMOVA and PCoA results. Therefore, G. microrrhynchum populations seem to have been isolated for a long period without any genetic exchange among them, which might be due to these populations being restricted to areas such as mountaintops. Chang et al. (2004) studied the genetic diversity of G. microrrhynchum populations using allozymes, and similar to our results $\left(F_{\mathrm{ST}}=0.6818\right)$, they found that total genetic differentiation was mainly caused by variations among populations (genetic differentiation coefficient, $G_{\mathrm{ST}}=$ $0.627)$. Their results also revealed higher genetic diversity at the species level $(\mathrm{PPB}=35.7 \%)$ than at the population level $(\mathrm{PPB}=10.1 \%)$, although their values were lower than those obtained in the present study. Differences in diversity values between studies are probably due to differences in the markers used, e.g., allozymes vs RAPD. RAPD markers target the entire genome, and thereby detect more loci than do allozymes (Nybom, 2004).

According to Hamrick et al. (1992), the genetic diversity of a plant population depends upon the extent of its regional distribution, age and size, breeding system, seed dispersal, and life history. Nybom and Bartish (2000) investigated the relationship between life history traits and genetic diversity, as measured by RAPD markers, within and among populations, and found that the breeding system greatly influenced the genetic diversity of populations. According to Nybom's (2004) results, the $F_{\mathrm{ST}}$ value obtained between $G$. microrrhynchum populations $(0.6818)$ is similar to that of self-pollinating plants $\left(F_{\mathrm{ST}}=0.70\right)$, and markedly different to that of plants with outcrossing $\left(F_{\mathrm{ST}}=0.28\right)$ or mixed breeding systems $\left(F_{\mathrm{ST}}=\right.$ 0.27). Chang et al. (2004) suggested that G. microrrhynchum is a self-pollinating plant, based on field observations of successful fruit production despite the absence of a specific pollinator. Based on these results, G. microrrhynchum appears to rely on self-pollination mechanisms. The Mantel test, UPGMA cluster analysis, and PCoA indicate that there was no significant relationship between the geographical and genetic distances, and this is generally observed in self-pollinating species (Nevo et al., 1998), except when geographical distances are extremely

Genetics and Molecular Research 15 (4): gmr15048843 
high (Gabrielsen et al., 1997). In addition, Chang et al. (2004) indicated that the fruit of $G$. microrrhynchum has no dispersal vector, and is dispersed by gravity. This restricted seed vagility might decrease gene flow between populations (Liu et al., 2016b) and expand the distributional range of local populations, leading to their restriction to local environments to which they become adapted. In addition, differentiated small local populations may exhibit increased disagreement between genetic and geographical distances due to genetic drift (Fischer and Matthies, 1998). The gene flow calculated for G. microrrhynchum populations based on $F_{S T}$ values $\left(N_{\mathrm{m}}=0.117\right)$ suggests a low level of gene exchange among local populations. In species with low levels of gene flow $\left(N_{\mathrm{m}}<1\right)$, genetic drift is usually the predominant factor that shapes populations' genetic structures (Liu et al., 2011). Therefore, the low levels of gene flow found in the present study suggest that genetic drift has affected the genetic composition of G. microrrhynchum populations.

\section{Natural history of G. microrrhynchum populations}

The G. microrrhynchum populations exhibited increasing genetic diversity with increasing latitude (Figure 3). This suggests that G. microrrhynchum is a north-origin relict plant (Kong, 2002). Such boreal plants probably moved south to seek refuge from the cold and dry climatic characteristic of the Ice Age during the Late Pleistocene, and settled in a high-mountain area within the Korean Peninsula. During the following warm interglacial or post-glacial age, competition with other southern plants may have instigated their return to northern areas, or their restriction to high mountains. In this period, high mountains provided suitable refugia for boreal plants, which changed their distributional elevations according to the inter-glacial and cold glacial Quaternary climatic cycles (Chung et al., 2012). Within the Korean Peninsula, these glacial relict species are mainly distributed in the high-mountain area of Baekdudaegan (Kong, 2002). This area is thought to have contained refugia of various sizes, and provided a stable macrorefugia for almost all boreal plant species.

The low levels of genetic diversity found for each of the seven G. microrrhynchum populations studied, their high genetic differentiation, and low level of gene flow, suggest that extant populations originated in several small, isolated microrefugia within Baekdudaegan (Chung et al., 2012). G. microrrhynchum was expected to exhibit a low level of gene flow between populations, given its autogamous mating system and gravity-dispersed seeds, and the fact that it is found in temperature-sensitive habitats. The very low gene flow value obtained in the present study is consistent with the results of Chang et al. (2004) using allozymes. However, other authors have noted that most glacial relict species inhabiting the Korean Peninsula survived in large and stable macrorefugia within the Baekdudaegan area, as these plant species exhibited high genetic diversity within populations and low genetic differentiation (Chung et al., 2001, 2009, 2012, 2013). Such differences are probably related to the ecological characteristics of each species. Similar to G. microrrhynchum populations, Kirengeshoma koreana populations also survived in small isolated microrefugia, exhibit low levels of genetic diversity, high levels of genetic differentiation, and low levels of gene flow among them (Chung et al., 2013). Therefore, the ecological traits of G. microrrhynchum probably contributed to the species' survival in small and isolated microrefugia in Baekdudaegan during the Ice Age, like K. koreana. In addition, G. microrrhynchum populations might be greatly affected by climate change and increasing temperature, due to a reduction in gene flow between populations and their isolation on mountaintops. Ecological and genetic studies, including of the species'

Genetics and Molecular Research 15 (4): gmr15048843 
center of distribution in Northeast Asia, would contribute to a better understanding of the status of G. microrrhynchum populations on the Korean Peninsula, which is the southern limit of its global distribution.

\section{Conservation implications}

Climate change and/or global warming are particularly threatening to organisms that are isolated to cool or cold habitats, such as boreal and alpine plants and animals (Nair et al., 2014), including G. microrrhynchum populations that inhabit the slopes of Baekdudaegan on the Korean Peninsula (Chang et al., 2004). For designing management and protection programs under a climate change scenario, species genetic variability has received special attention in the past few years (Nair et al., 2014). The successful management and conservation of natural populations depend upon an accurate assessment of their genetic diversity, in order to address questions regarding genetic relationships among individuals as well as the level and structure of genetic variation (Nair et al., 2014). As the evolutionary potential of a species to cope with an ever-changing environment depends upon its level of genetic variability (Avise and Hamrick, 1996), knowledge of genetic diversity and structure among populations is required for developing appropriate conservation and management strategies. In general, if alpine and subalpine forest ecosystems are disturbed or destroyed, it is almost impossible to return them to their original status, or it could take a very long time because of low system productivity in adverse weather conditions (Grabherr et al., 1994). Because all known populations of G. microrrhynchum inhabit alpine or subalpine areas, the destruction of vegetation by anthropogenic activity will have a seriously adverse effect on population survival. In order to minimize G. microrrhynchum habitat fragmentation and destruction, it is essential to establish a restricted-access conservation area. In addition, conservation efforts should be directed to the present buffer zones, and to the estimated distribution area. Our genetic survey of G. microrrhynchum populations inhabiting the Baekdudaegan mountains on the Korean Peninsula revealed high genetic differentiation and low gene flow among populations and low genetic diversity within populations, which all reflect their characteristically isolated habitats. Furthermore, G. microrrhynchum has an autogamous mating system and its seeds are dispersed by gravity. Therefore, natural contact between local populations over environmental barriers is unfeasible, and each population is almost independently distributed genetically and geographically, which was reflected in the nonsignificant relationships we found between the genetic and geographical distances between them. The higher genetic diversity at the species level than at the population level, and the remarkable gradient of genetic diversity that corresponded with the latitudinal gradient, also indicate that these populations have evolved independently from a northern-origin population. Therefore, it is essential to protect and manage all populations, rather than focus on particular ones, in order to maintain the genetic diversity of G. microrrhynchum.

\section{Conflicts of interest}

The authors declare no conflicts of interest.

\section{ACKNOWLEDGMENTS}

We are grateful to all of the participants of this study.

Genetics and Molecular Research 15 (4): gmr15048843 


\section{REFERENCES}

Avise JC and Hamrick JL (1996). Conservation genetics: case histories from nature. Chapman and Hall, London.

Chang CS, Kim H, Park TY and Maunder M (2004). Low levels of genetic variation among southern peripheral populations of the threatened herb, Leontice microrhyncha (Berberidaceae) in Korea. Biol. Conserv. 119: 387-396. http://dx.doi. org/10.1016/j.biocon.2003.12.003

Chang CS, Lee HS, Park TY and Kim H (2005). Reconsideration of rare and endangered plant species in Korea based on the IUCN red list categories. Korean J. Ecol. 28: 305-320.

Chung JM, Park KW, Lee CS, Chung SH, et al. (2009). Contrasting levels of genetic diversity between the historically rare orchid Cypripedium japonicum and the historically common orchid Cypripedium macranthos in South Korea. Bot. J. Linn. Soc. 160: 119-129. http://dx.doi.org/10.1111/j.1095-8339.2009.00965.x

Chung MG, Chung MY and Epperson BK (2001). Conservation genetics of an endangered herb, Hanabusaya asiatica (Campanulaceae). Plant Biol. 3: 42-49. http://dx.doi.org/10.1055/s-2001-11744

Chung MY, López-Pujol J, Maki M, Kim KJ, et al. (2012). Genetic diversity in the common terrestrial orchid Oreorchis patens and its rare congener Oreorchis coreana: inference of species evolutionary history and implications for conservation. J. Hered. 103: 692-702. http://dx.doi.org/10.1093/jhered/ess032

Chung MY, Moon MO, López-Pujol J, Chung JM, et al. (2013). Genetic diversity in the two endangered endemic species Kirengeshoma koreana (Hydrangeaceae) and Parasenecio pseudotaimingasa (Asteraceae) from Korea: Insights into population history and implications for conservation. Biochem. Syst. Ecol. 51: 60-69. http://dx.doi.org/10.1016/j. bse.2013.08.017

Excoffier L, Laval G and Schneider S (2007). Arlequin (version 3.0): an integrated software package for population genetics data analysis. Evol. Bioinform. Online 1: 47-50.

Fischer M and Matthies D (1998). RAPD variation in relation to population size and plant fitness in the rare Gentianella germanica (Gentianaceae). Am. J. Bot. 85: 811-819. http://dx.doi.org/10.2307/2446416

Frankham R, Briscoe DA and Ballou JD (2002). Introduction to conservation genetics. Cambridge University Press, Cambridge.

Gabrielsen TM, Bachmann K, Jakobsen KS and Brochmann C (1997). Glacial survival does not matter: RAPD phylogeography of Nordic Saxifraga oppositifolia. Mol. Ecol. 6: 831-842. http://dx.doi.org/10.1111/j.1365294X.1997.tb00137.x

Grabherr G, Gottfried M and Paull H (1994). Climate effects on mountain plants. Nature 369: 448. http://dx.doi. org/10.1038/369448a0

Hamrick JL, Godt MJW and Sherman-Broyles SL (1992). Factors influencing levels of genetic diversity in woody plant species. In: Population genetics of forest trees (Adams WT, Strauss SH, Copes DL and Griffin AR, eds.). Kluwer Academic Publishers, Netherlands, 95-124.

Hewitt GM (2004). Genetic consequences of climatic oscillations in the Quaternary. Philos. Trans. R. Soc. Lond. B Biol. Sci. 359: 183-195, discussion 195. http://dx.doi.org/10.1098/rstb.2003.1388

Kong WS (2002). Species composition and distribution of Korean alpine plants. J. Korean Geogr. Soc. 37: 357-370.

Kong WS and Lim JH (2008). Disjunctive distribution of Vaccinium vitis-idaea and thermal condition. J. Korean Geogr. Soc. 43: 495-510.

Korean National Arboretum (2012). Rare plants in Korea data book. Korea National Arboretum, Suwon.

Lee SH, Yeon MH and Shim JK (2011). Habitat and distribution feature of endangered species Leontice microrhyncha S. Moor. Korean J. Env. Ecol 25: 819-827.

Lee TB (2003). Illustrated flora of Korea. Hyang-mun Sa Publishing Co., Seoul.

Lee WC (1997). Coloured standard illustrations of Korean plants. Academy Publishing Co., Seoul.

Liu XL, Qian ZG, Liu FH, Yang YW, et al. (2011). Genetic diversity within and among populations of Neopicrorhiza scrophulariiflora (Scrophulariaceae) in China, an endangered medicinal plant. Biochem. Syst. Ecol. 39: 297-301. http://dx.doi.org/10.1016/j.bse.2011.03.004

Liu Z, Shu Q, Wang L, Yu M, et al. (2012). Genetic diversity of the endangered and medically important Lycium ruthenicum Murr. revealed by sequence-related amplified polymorphism (SRAP) markers. Biochem. Syst. Ecol. 45: 86-97. http://dx.doi.org/10.1016/j.bse.2012.07.017

Liu W, Wang J, Yin DX, Yang M, et al. (2016a). Genetic diversity and structure of the threatened species Sinopodophyllum hexandrum (Royle) Ying. Genet. Mol. Res. 15: http://dx.doi.org/10.4238/gmr.15028130.

Liu HL, Zhang RQ, Geng ML, Zhu JY, et al. (2016b). Chloroplast analysis of Zelkova schneideriana (Ulmaceae): genetic diversity, population structure, and conservation implications. Genet. Mol. Res. 15: http://dx.doi.org/10.4238/ gmr.15017739.

Genetics and Molecular Research 15 (4): gmr15048843 
Mantel N (1967). The detection of disease clustering and a generalized regression approach. Cancer Res. 27: 209-220. Ministry of Environment (2012). Natural Conservation Act. Available at [http://www.me.go.kr/home/web/main.do].

Nair VD, Raj RPD, Panneerselvam R and Gopi R (2014). Assessment of diversity among populations of Rauvolfia serpentina Benth. Ex. Kurtz. from Southern Western Ghats of India, based on chemical profiling, horticultural traits and RAPD analysis. Fitoterapia 92: 46-60. http://dx.doi.org/10.1016/j.fitote.2013.09.017

Nei M (1978). Estimation of average heterozygosity and genetic distance from a small number of individuals. Genetics 89: $583-590$.

Nevo E, Baum B, Beiles A and Johnson DA (1998). Ecological correlates of RAPD DNA diversity of wild barley, Hordeum spontanuem, in the Fertile Crescent. Genet. Resour. Crop Evol. 45: 151-159. http://dx.doi. org/10.1023/A:1008616923427

Nybom H (2004). Comparison of different nuclear DNA markers for estimating intraspecific genetic diversity in plants. Mol. Ecol. 13: 1143-1155. http://dx.doi.org/10.1111/j.1365-294X.2004.02141.x

Nybom H and Bartish IV (2000). Effects of life history traits and sampling strategies on genetic diversity estimated obtained with RAPD markers in plants. Perspect. Plant Ecol. Evol. Syst. 3: 93-114.

Peakall ROD and Smouse PE (2006). GENALEX 6: genetic analysis in Excel. Population genetic software for teaching and research. Mol. Ecol. Notes 6: 288-295.

Rodrigues L, van den Berg C, Póvoa O and Monteiro A (2013). Low genetic diversity and significant structuring in the endangered Mentha cervina populations and its implications for conservation. Biochem. Syst. Ecol. 50: 51-61. http:// dx.doi.org/10.1016/j.bse.2013.03.007

Slatkin M and Barton NH (1989). A comparison of three indirect methods for estimating average levels of gene flow. Evolution 43: 1349-1368. http://dx.doi.org/10.2307/2409452

Trindade H, Sena I, Gonçalves S and Romano A (2012). Genetic diversity of wild populations of Tuberaria major (Cistaceae), an endangered species endemic to the Algarve region (Portugal), using ISSR markers. Biochem. Syst. Ecol. 45: 49-56. http://dx.doi.org/10.1016/j.bse.2012.06.028

Viana e Souza HA and Lovato MB (2010). Genetic diversity and structure of the critically endangered tree Dimorphandra wilsonii and of the widespread in the Brazilian Cerrado Dimorphandra mollis: Implications for conservation. Biochem. Syst. Ecol. 38: 49-56. http://dx.doi.org/10.1016/j.bse.2009.12.038

Yeh FC and Boyle TJB (1997). Population genetic analysis of co-dominant markers and quantitative traits. Belg. J. Bot. 129: 157-163.

Yim YJ (1977). Distribution of forest vegetation and climate in the Korean Peninsula. 3: Distribution of tree species along the thermal gradient. Jap. J. Ecol. 27: 177-189.

Yim YJ and Kira T (1975). Distribution of forest vegetation and climate in the Korean Peninsula. I. Distribution of some indices of thermal climate. Jap. J. Ecol. 25: 77-88.

Yu HH, Yang ZL, Sun B and Liu RN (2011). Genetic diversity and relationship of endangered plant Magnolia officinalis (Magnoliaceae) assessed with ISSR polymorphisms. Biochem. Syst. Ecol. 39: 71-78. http://dx.doi.org/10.1016/j. bse.2010.12.003

Genetics and Molecular Research 15 (4): gmr15048843 